\title{
Sipuleucel-T Regimen
}

National Cancer Institute

\section{Source}

National Cancer Institute. Sipuleucel-T Regimen. NCI Thesaurus. Code C160813.

An autologous cellular immunotherapy regimen that may be used in the treatment of metastatic, hormone refractory prostate cancer. 